\title{
Correlation between Working Postures and Musculoskeletal Disorders Complaints Suffered by the Fishermen in Tanjung Village, Sumenep District
}

\section{Hubungan antara Posisi Kerja dengan Keluhan Musculoskeletal Diseases pada Nelayan di Desa Tanjung, Kabupaten Sumenep}

\author{
Nefri Daika \\ PT Sebastian Jaya Metal \\ Blok F Jalan Jababeka X Kawasan Industri Jababeka I No, RT.5, Harja Mekar \\ Cikarang Utara, Bekasi, West Java 17530, Indonesia
}

\begin{abstract}
Introduction: The working activities of the fishermen in Tanjung Village are still considered traditional works, providing that the works are done manually with non-ergonomic working postures, such as bending, standing, squatting, and legs bending. Accordingly, these postures trigger the complaints of musculoskeletal disorders (MSDs). Musculoskeletal disorders are injuries or pains in the skeletal muscles, for example, discomfort, ache, pins and needles, and heat. Working as a fisherman means dedicates half of a person's time to catch fishes mostly by using traditional boats and equipment. Thus, a lot of fishermen are discovered complaining about pains after completing their work. This research aims to distinguish the correlation among variables. Methods: This research is observational research that applies the cross-sectional design. The samples of this research are 56 fishermen selected by implementing the cluster random sampling technique. The data are obtained by completing measurements, interviews, and observations by applying the Rapid Entire Body Assessment (REBA) method and by distributing the Nordic Body Map (NBM) questionnaires. Results: As a result, there are 73.2\% fishermen have a high risk of musculoskeletal disorders, and $46.4 \%$ have been working in high-risk working postures. Conclusion: It can be concluded that the working postures have a mild correlation $(\mathrm{r}=0.407)$ with musculoskeletal disorders complaints.
\end{abstract}

Keywords: fishermen, complaints of musculoskeletal disorders, Nordic Body Map, Rapid Entire Body Assessment

ABSTRAK

Pendahuluan: Aktivitas kerja nelayan di Desa Tanjung masih merupakan pekerjaan tradisional dan dengan pekerjaan yang dilakukan masih secara manual dengan posisi kerja tidak ergonomis seperti membungkuk, berdiri, jongkok, dan kaki ditekuk. Hal tersebut berisiko menyebabkan gangguan keluhan nyeri pada otot skeletal. Keluhan muskuloskeletal merupakan keluhan yang dirasakan pada otot skeletal seperti rasa nyeri, pegal-pegal, kesemutan, dan rasa panas. Bekerja sebagai nelayan akan banyak menghabiskan separuh waktunya untuk menangkap ikan dengan menggunakan perahu dengan peralatan yang tradisional. Oleh sebab itu, banyak nelayan yang mengeluhkan rasa nyeri setelah melakukan pekerjaannya. Tujuan dari penelitian ini untuk mengetahui adanya hubungan antar variabel. Metode: Penelitian ini merupakan penelitian observasional dengan desain penelitian cross-sectional. Sampel penelitian sebanyak 56 nelayan dengan menggunakan teknik cluster random sampling. Data didapatkan dengan cara pengukuran, wawancara, dan observasi menggunakan metode Rapid Entire Body Assessment (REBA) dan pengisian kuesioner dengan metode Nordic Body Map (NBM) oleh nelayan. Analisis hubungan menggunakan uji Spearman's rho. Hasil: Sebanyak 73,2\% nelayan memiliki tingkat risiko keluhan muskuloskeletal tinggi, dan 46,4\% nelayan memiliki posisi kerja dengan tingkat risiko sangat tinggi. Simpulan: Berdasarkan hasil penelitian dapat disimpulkan bahwa posisi kerja nelayan memiliki hubungan dengan keluhan muskuloskeletal dengan tingkat hubungan yang lemah $(r=0,407)$ antara posisi kerja dengan keluhan muskuloskeletal.

Kata kunci: nelayan, Nordic Body Map, Rapid Entire Body Assessment, keluhan musculoskeletal

\author{
Author for Correspondence: \\ Nefri Daika \\ Email: daikanefri@gmail.com \\ Telephone: +6281230122972
}

(C2019 IJOSH All right reserved. Open access under CC BY NC-SA license doi: 10.20473/ijosh.v8i3.2019.258-264 Received July 09, 2018 received in revised form February 08, 2019, Accepted November 04, 2019, Published: December 2019 


\section{INTRODUCTION}

The development in Indonesia influences the development of various sectors, whether it is industrial or fishery sector. Therefore, along with the improvement of those sectors, the enactment of occupational safety and health must be implemented both in formal and informal sectors. However, the implementation of occupational safety and health in informal sectors is often less noticed by the government.

The implementation of occupational safety and health is intended to protect the workers in a workplace to avoid the risk of occupational diseases as well as the risk of being exposed to the potential hazard in the workplace. In addition, by enacting occupational safety and health, the workers can work safely and comfortably to achieve a high productivity level. According to Ministry of Manpower and Transmigration (2003), it was defined that an employee is every person who is able to work or to produce goods and services to fulfill the needs of her/himself or the society.

In completing the works as well as in increasing productivity, the workers need to be able to operate the working equipment and technology. Nonetheless, in order to achieve the highest productivity level, the workers are required to be familiar with how to adjust themselves to the working equipment, working processes, and working environment, depending on their working site (Sholihah, 2013).

Ergonomic is a multidisciplinary science that learns about the principles in designing working equipment, machine, working process, and working environment in accordance with the work performed (Tarwaka, 2014). There are several objectives of this science, such as to minimize the risk of injury, increase working productivity, and prevent occupational diseases, for example, low back pain, back pain, and Musculoskeletal Disorders (MSDs).

Musculoskeletal diseases (MSDs) are ergonomic problems that often experienced by the workers, especially to muscular strength and endurance while performing the works. Furthermore, MSDs may arise due to repeated working postures anmovements. In consequence, a heavy workload that is completed in a non-ergonomic posture requires the workers to exert excessive energy that can result in the MSDs complaints and early fatigue (Kurnianto, 2017).

The MSDs complaints are reportedly suffered by every worker, whether s/he comes from the fishery sector or not. However, for fishermen, they are indeed familiar with non-ergonomic working postures, such as bending, twisting, squatting, and carrying heavy goods, which can result in pain in several parts of the body. Besides, this will affect their productivity and performance, which in the end, may trigger the risk of abnormalities in bone shape. These non-ergonomic working postures, particularly of the fishermen as the samples of this research, can be analyzed by applying the Rapid Entire Body Assessment (REBA) method.

Based on the survey conducted by the Occupational Safety and Health Administration in Europe, in 2010, there were 49 reported cases of MSDs in the fishery sector only. The MSDs were mostly felt in the shoulders, arms, and neck, which is in accordance with the fact that the MSDs in the upper body are more recurring than the MSDs in the lower body (Occupational Safety and Health Administration, 2016). According to the International Labour Organization (2013) ) during The Prevention of Occupational Diseases program, it was ascertained that the MSDs complaints are included in the Carpal Tunnel Syndrome (CTS), which was reported as the majority $(59 \%)$ of the occupational diseases in Europe in 2005.

World Health Organization (WHO) in 2005 also reported that more than $10 \%$ of the registered cases on the occupational diseases were about MSDs complaints. In Korea, the case of MSDs experienced a significant increase from 1,634 cases in 2001 to 5,502 cases in 2010. Furthermore, in Great Britain, in 2011-2012, 40\% of occupational diseases were related to MSDs. Moreover, in Argentina, there were allegedly 22,013 cases of MSDs. Additionally, in Japan, 7.779 cases in 2011 regarding lower back pain were recorded.

Referring to Health Research and Development Agency (2013), the highest prevalence of MSDs was recorded at $31.2 \%$ that occurred in the occupations of fishermen, farmers, and laborers. Meanwhile, according Ministry of Health of the Republic of Indonesia (2009) the research from the Ministry of Health of the Republic of Indonesia indicated that approximately $40.5 \%$ of occupational diseases were related to the occupation. Additionally, denoting the research conducted by Jalajuwita and Paskarini (2015) with the subject of 9,482 workers in 12 districts in Indonesia, it was discovered that several occupational diseases were suffered by the workers, such as MSDs (16\%), cardiovascular diseases (8\%), nerve diseases (6\%), breathing problems (3\%), and ear, nose, and throat (ENT) disorders (1.5\%). 
Research regarding occupational diseases, particularly on MSDs as a disease suffered by most workers, have been carried out plenty of times. MSDs are mainly caused by non-ergonomic working postures. Working postures refer to body postures while completing a work; thus, non-ergonomic working postures will affect the productivity of the workers.

According to Ministry of Law and Human Rights of the Republic of Indonesia (2016), fishermen are every person whose livelihood is fishing. The stages carried out by fishermen when fishing consist of the preparation (preparing fishing equipment), fishing (lowering the net), drawing the net, and collecting the catch. Those working processes require energy exertion that results in the muscle stretches that exceed the maximum limit of muscle work. If this continuously happens, it is likely that the skeletal muscle will suffer from injuries (Tarwaka, 2011).

The research authored by Krisdianto, Sujoso and Hartanti (2015) on the MSDs complaints suffered by the fishermen showed that 92 respondents (83.7\%) suffered from mild MSDs, while 16.3\% of the respondents suffered from moderate MSDs. Besides, another research conducted by Budiman (2015) revealed that good working postures (47.1\%) resulted in mild MSDs (43.8\%). Moreover, it was discovered that low back pain was the highest case of MSDs suffered by the fishermen whose working postures are considered awkward.

The data of the Central Bureau of Statistics in 2011 exposed that around 8,090 coastal villages that spread in 300 districts in Indonesia with the number of populations as many as 7.87 million were workers in informal sectors, and $30 \%$ of it were fishermen. Nonetheless, the potential manpower in Indonesia had not yet been fully employed due to the low human resources of fishermen and inadequate infrastructures (Directorate General of Public Health and Occupational Health Development, 2014).

Based on the aforementioned background, this research aims to discover the correlation between working postures and MSDs complaints suffered by fishermen in Tanjung Village.

\section{METHODS}

This research implemented an observational method along with the cross-sectional design, providing both the independent and dependent variables which were scrutinized in a certain period of time. The total population of this research was 124 fishermen from four villages. However, the samples only consisted of 56 fishermen who were selected by using the cluster random sampling technique.

The data was collected from November 2017 until May 2018 with the variables of working postures and MSDs complaints to be analyzed. The primary data collection was completed by conducting observations and interviews, as well as distributing the Nordic Body Map (NBM) questionnaires to be filled by the fishermen to ascertain the pain they felt. The observation was acted out from 06:00 WIB until evening. Meanwhile, the secondary data was obtained from the village profile and an interview with the fishermen.

After all the data had been obtained, it was then analyzed through editing, coding, processing, and cleaning processes. The data obtained from the NBM questionnaires and interviews, as well as the measurements of the fishermen's weight and height, were scrutinized in the form of the narration, table, and cross-tabulation to present, while the correlation of the variables was tested by implementing the Spearman's Rho correlation test.

\section{RESULTS}

\section{The Distribution of Fishermen Working Postures}

To distinguish the working postures of the fishermen, an assessment by using the REBA method was carried out. The assessment method was completed by observing each of the fishermen's working postures when working. The results of REBA assessment consisted of three groups; A, $\mathrm{B}$, and $\mathrm{C}$. Thereafter, the determination of the final score was completed by adding the scores of group $\mathrm{C}$ to the muscle activities performed by the fishermen. The final score is presented in Table 1.

Table 1 indicated that from a total of 56 fishermen, 26 of them (46.4\%), according to the REBA method, have a very high risk of working postures. In addition, one of the working postures based on the scoring of the REBA method, for instance, the working posture which final score is 11, can be seen in Figure 1 that portrays the working posture with the highest risk level; that is when a fisherman bends to collect the catch.

By implementing the REBA method, the analysis of the working postures in Figure 1 was divided into 2 categories, namely scoring group A 
and $\mathrm{B}$. The scoring group A consisted of the bending of the body with the flexion of $0^{\circ}-60^{\circ}$ which score was 3 with an additional change score of 1 . The bending and twisting neck with the flexion of $>20^{\circ}$ obtained a score of 2 with an additional change score of 1 . The legs posture attained a score of 2 with an additional change score of 2 . In results, the measurement of the body, neck, and leg postures obtained a final score of 9 and was converted into Table A.

On the other hand, the scoring group $\mathrm{B}$ comprised that the arm posture with the flexion of

Table 1. The Distribution of Risk Level of Working Postures Made by the Fishermen in Tanjung Village in 2018 According to the REBA Method

\begin{tabular}{ccc}
\hline $\begin{array}{c}\text { Risk Level of } \\
\text { Working Posture }\end{array}$ & Frequency & Percentage (\%) \\
\hline Moderate & 12 & 21.4 \\
High & 18 & 32.1 \\
Very high & 26 & 46.4 \\
\hline Total & 56 & 100 \\
\hline
\end{tabular}

Table 2. The Distribution of the MSDs Complaints Suffered by the Fishermen in Tanjung Village in 2018

\begin{tabular}{ccc}
\hline $\begin{array}{c}\text { Complaints of } \\
\text { MSDs Level }\end{array}$ & Frequency & Percentage (\%) \\
\hline Low & 15 & 26.8 \\
High & 41 & 73.2 \\
\hline Total & 56 & 100 \\
\hline
\end{tabular}

Table 3. The Correlation between Working Postures and MSDs Complaints Suffered by the Fishermen in Tanjung Village in 2018

\begin{tabular}{|c|c|c|c|c|c|c|}
\hline \multirow{3}{*}{$\begin{array}{c}\text { Risk } \\
\text { Level of } \\
\text { Working } \\
\text { Posture } \\
\end{array}$} & \multicolumn{4}{|c|}{ Complaints of MSDs Level } & \multirow{2}{*}{\multicolumn{2}{|c|}{ Total }} \\
\hline & \multicolumn{2}{|c|}{ Moderat } & \multicolumn{2}{|c|}{ High } & & \\
\hline & $\mathbf{n}$ & $\%$ & n & $\%$ & $\mathbf{N}$ & $\%$ \\
\hline Moderate & 6 & 50 & 6 & 50 & 12 & 100 \\
\hline High & 7 & 38.9 & 11 & 61.1 & 18 & 100 \\
\hline Very High & 2 & 7.7 & 24 & 92.3 & 26 & 100 \\
\hline P-Value & \multicolumn{6}{|c|}{0.002} \\
\hline $\mathrm{r}$ & \multicolumn{6}{|c|}{0.407} \\
\hline
\end{tabular}

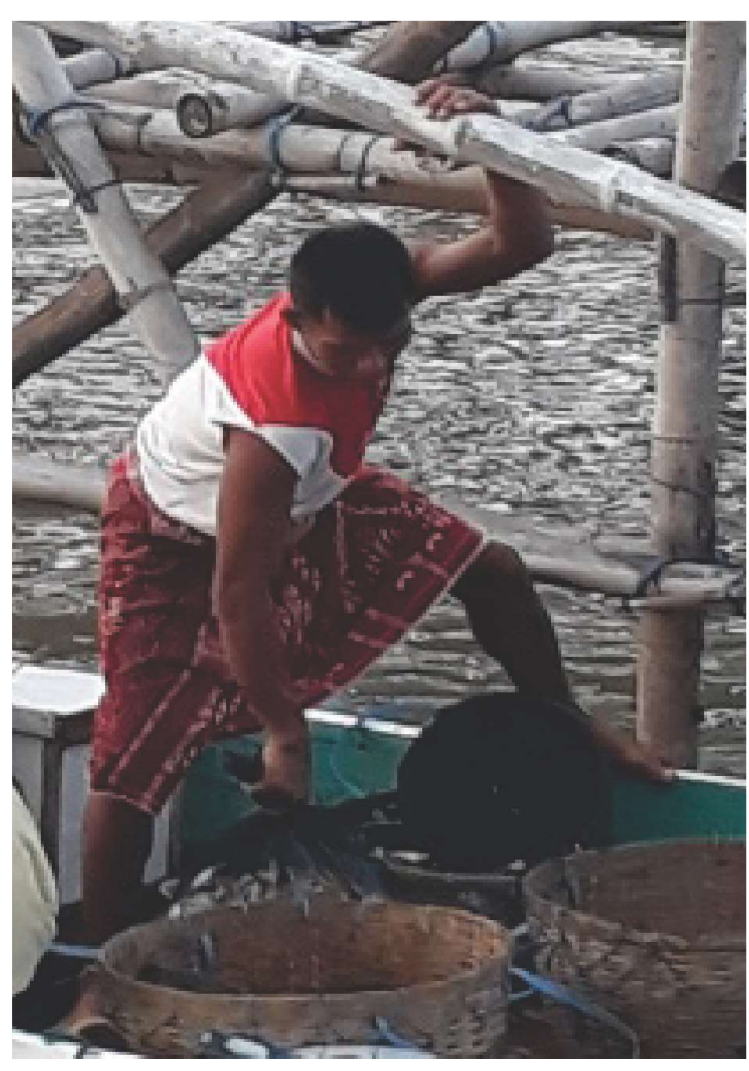

Figure 1. A Fisherman Collecting His Catch

$>90^{\circ}$ attained a score of 4 with an additional score change of -1 . In addition, lower arm postures with the flexion of $60^{\circ}-100^{\circ}$ obtained a score of 1 , while wrist postures with the flexion of $>15^{\circ}$ acquired a score of 2. As a result, the obtained final score of the measurements of the upper arm, lower arm, and wrist postures was 4 before converted into Table B.

The result of the calculation of Table A was then added with the weight lifted with a score of 1 . Thus, the total score of Table A was 10. Furthermore, the result of Table B was added to the type of equipment held with a score of 1 . Conclusively, it was obtained that 5 was the total score of Table B.

Furthermore, scores of Tables A and B were converted into Table $\mathrm{C}$ as the last stage and obtained a score of 11. In order to determine the final score of the REBA, the score of Table $\mathrm{C}$ was added with the types of muscle activities performed by the fishermen, which had a score of 1 (unstable postures while working). Hence, the final score of the REBA method was 12 , which belongs to a high level of risk and in need of immediate actions. 


\section{The Distribution of the Fishermen MSDs Complaints}

The MSDs complaints discovered in this research comprised the complaints of discomfort, pain, heat, ache, and pins and needles in the skeletal muscles. Referring to the NBM scoring instrument, the discomfort felt by the fishermen can be classified into four groups, namely mild, moderate, severe, and very severe.

Table 2 displayed the majority of the fishermen, that is as many as 41 people (73.2\%), suffer from the high-risk level of MSDs. In other words, it can be stated that this showed that most of the fishermen had been working non-ergonomically.

\section{The Correlation between Working Postures and MSDs Complaints Suffered by the Fishermen}

The results of the analysis by implementing the Spearman's Rho correlation test between variables are disclosed in Table 3. Table 3 affirmed that as many as 24 fishermen $(92.3 \%)$ who had been working with very high-risk level working postures suffered from a high-level of MSDs. Furthermore, the result of the correlation level between variables showed a score of 0.407 , which indicated that working postures have a positive moderate correlation with the MSDs complaints. Moreover, the result of the Spearman's Rho correlation test produced a score of 0.002 with $\alpha$ $=0,05$ that categorized as a significance. In other words, this pointed out that there is a correlation between working postures and MSDs complaints suffered by the fishermen.

\section{DISCUSSION}

\section{Fishermen Working Postures}

From the result of the analysis displayed in Table 1, it can be perceived that almost all of the fishermen are working with the very high-risk level postures. Whereas, working postures are the main factors that influence the occurrence of MSDs. Besides, referring to the results of the working position observation in Table 1, it was discovered that more than half of the fishermen carried out their work in very high-risk level postures which the REBA score was $>11$. This score was attained by discerning the postures the fishermen made while they are working.
The postures that are usually made by the fishermen comprise of bending, standing with a pedestal on both legs, bowing, squatting, twisting the wrists, and legs bending postures. However, it was noticed that most of the samples' working positions were bending, bowing, squatting, and legs bending.

After the observation had been completed, the assessment by using the REBA method was carried out to determine whether the risk level of the MSDs complaints needs immediate actions. The REBA method is one method that is usually used in analyzing working postures due to the fact that this method is believed sensitive to every sudden change of working postures (Tarwaka, 2015). Moreover, additional scores need to be added to acquire total scores that are listed in Tables A and B if there is a change of working postures. The total result of Table A was added with the workload while working to attain score A. Meanwhile, the total result of Table B was added to the type of equipment to obtain score B. Both scores A and B were scrutinized into Table $\mathrm{C}$ to be added with the type of muscle activities when the fishermen work. Thus, the final sum in Table $\mathrm{C}$ is claimed as the final score. The final score is used to determine the risk level of the MSDs as well as the prevention required.

The result of the analysis of the working posture when the fishermen draw the catch indicated that commonly, they complete their work in a very highrisk level of working postures which score was $>11$. The postures usually made by the fishermen when collecting the catch were bending, standing with the pedestal on the arm muscles, and legs bending. Therefore, in order to complete the work safely and comfortably, it is indeed compulsory to make as comfortable and ergonomic postures as possible (Merulalia, 2010).

\section{MSDs Complaints}

The result of the scrutinization regarding the MSDs complaints displayed in Table 2 showed that almost all of the fishermen have a high-risk level of MSDs. The MSDs complaints are complaints felt by the fishermen in the form of discomfort, pain, heat, ache, and pins and needles in the skeletal muscles, such as tendons, joints, and ligaments. Thus, a heavy workload tends to have a higher risk of the MSDs than a mild workload (Tarwaka, 2014). Additionally, the results of this research are in line with the results of the research conducted by Putri (2017), which 
affirmed that most of the respondents suffered from the high-risk level of MSDs.

The assessment of the MSDs complaints was completed by referring to the NBM questionnaires to determine the pain level felt by the fishermen in the skeletal muscles, namely tendons, joints, and ligaments. The questionnaires consisted of 27 parts of the skeletal muscles that were divided into the right part and the left part of the body. The assessment of the NBM questionnaires was done by fulfilling the scores and emphasizing body parts. The assessment of the NBM questionnaires consists of 4 score categorizations, namely category 1 (no pain), category 2 (mild pain), category 3 (moderate pain), and category 4 (severe pain). The scores obtained from the right and left parts of the body were added to acquire the final score to determine the risk level suffered by the fishermen.

The body parts that suffer from the MSDs were varied. However, it was noticed that the most dominant body parts complained suffering from the MSDs were the back, upper neck, lower back, and arms. These results are plausible due to the fact that most of the time, the postures made by the fishermen comprise standing with the pedestal on both legs, bending, and bowing. Moreover, these results are in accordance with Sastrowinoto (1985) who proposed that the works with static working postures are more familiar with the MSDs complaints around the lower back, neck, and back.

\section{The Analysis of the Correlation between Working Postures and MSDs Complaints}

The analysis of the working postures and MSDs complaints displayed in Table 3 asserted that based on the REBA method of assessment, most of the fishermen showed the very high-risk level of working postures along with the very high level of the MSDs complaints. Apparently, this because their working space is limited to certain postures aside from the fact that the works are performed by making awkward postures, such as bending, bowing, legs bending, squatting, and arms folding.

The results of the Spearman's Rho correlation test denoted that there is a correlation between working postures and MSDs complaints. The correlation score showed the number that indicates a positive moderate correlation between variables. The positive correlation means that there is a unidirectional correlation between the independent and dependent variables. Eventually, it can be stated that the higher the complaints felt by the fishermen, the higher the level of the MSDs.

Awkward postures are postures when body parts detached from the body gravitation, for example, arms and hands raising, bowing, head lifting, and many more. In addition, the more detached the body position from the body gravitation, the higher the complaints of disorders (Grandjean, 1993).

This research is in line with the theory proposed by Tarwaka (2014), which affirmed that awkward working postures are the postures that oppose natural postures. Other than that, this research is in accordance with the research conducted by Sang, Djajakusli and Russeng (2013), which stated that there is a correlation between working postures and MSDs complaints suffered by the palm oil harvesters. Another corresponding research result is the one carried out by Jalajuwita and Paskarini (2015) that concluded if there is a correlation between working postures and MSDs complaints suffered by the workers in the welding unit at PT Duta Hita Jaya Bekasi. . In addition, the result of this research is similar to the result of the research authored by Bedu, Russeng and Rahim (2013) which discovered that there is a significant correlation between working postures and MSDs complaints of the cleaning services in Regional Hospital of Dr. Wahidin Sudirohusodo, Makassar.

\section{CONCLUSION}

In accordance with the analysis conducted, it can be concluded that there is a moderate correlation between working postures and MSDs complaints with the value of $r=0.407$.

\section{ACKNOWLEDGMENT}

The authors would like to express their gratitude to the Almighty God, the supervisor who has guided and given advice for this research, and the fishermen who had been willing to be the respondents in this research so it can be properly completed.

\section{REFERENCES}

Bedu, H. H. S., Russeng, S. S. and Rahim, M. R. (2013) Faktor Yang Berhubungan Dengan Gangguan Muskuloskeletal Pada Cleaning Service Di Rsup Dr Wahidin Sudirohusodo Makasar. Scientific Articles. Makassar: Faculty of Public Health, Universitas Hasanuddin. 
Budiman, F. (2015) 'Hubungan Posisi Kerja Angkat dengan Keluhan Musculoskeletal Disorder pada Nelayan Tangkap di Muara Angke Kelurahan Pluit Jakarta Utara', Forum Ilmiah, 12(1), pp. 23-32.

Directorate General of Public Health and Occupational Health Development (2014) Pedoman Upaya Kesehatan Kerja bagi Masyarakat Perikanan (untuk Petugas Kesehatan). Jakarta: Ministry of Health of the Republic of Indonesia.

Grandjean, E. (1993) Fitting the Task to the Man: an Ergonomic Approach. 4th edn. London: Taylor \& Francis Ltd.

Health Research and Development Agency (2013) Riset Kesehatan Dasar. Jakarta.

International Labour Organization (2013) The Prevention of Occupational Diseases. Geneva: International Labour Organization.

Jalajuwita, R. N. and Paskarini, I. (2015) 'Hubungan Posisi Kerja dengan Keluhan Muskuloskeletal pada Unit Pengelasan PT. X Bekasi', The Indonesian Journal of Occupational Safety and Health, 4(1), pp. 33-42.

Krisdianto, Sujoso, A. D. P. and Hartanti, R. I. (2015) Hubungan Faktor Individu dan Fakator Pekerjaan dengan Keluhan Muskuloskeletal akibat Kerja (Studi pada Nelayan di Desa Puger Wetan Kecamatan Puger Kabupaten Jember ), Artikel Ilmiah Hasil Penelitian Mahasiswa. Jember: Faculty of Public Health, Universitas Jember.

Kurnianto, R. Y. (2017) 'Gambaran Postur Kerja dan Risiko Terjadinya Muskuloskeletal pada Pekerja Bagian Welding di Area Workshop Bay 4.2 PT. Alstom Power Energy Systems Indonesia', The Indonesian Journal of Occupational Safety and Health, 6(2), pp. 245-256.

Merulalia (2010) Postur Tubuh yang Ergonomis Saat Bekerja. Jakarta: Bhuana Ilmu Populer.

Ministry of Health of the Republic of Indonesia (2009) Profil Kesehatan Republik Indonesia
Tahun 2009. Jakarta: Ministry of Health of the Republic of Indonesia.

Ministry of Law and Human Rights of the Republic of Indonesia (2016) Undang-Undang Republik Indonesia Nomor 7 Tahun 2016 tentang Perlindungan Dan Pemberdayaan Nelayan, Pembudi Daya Ikan, Dan Petambak Garam. Jakarta: Ministry of Law and Human Rights of the Republic of Indonesia.

Ministry of Manpower and Transmigration (2003) Undang-undang Republik Indonesia No. 13 Tahun 2003 tentang Ketenagakerjaan. Jakarta: Kementerian Tenaga Kerja dan Transmigrasi.

Occupational Safety and Health Administration (2016) Musculoskeletal Disorders in Fisheries, OSH Wiki.

Putri, B. A. (2017) Faktor yang Berhubungan dengan Keluhan MSDs pada Pekerja bagian Produksi PT X Sidoarjo. Undergraduate Thesis. Surabaya: Faculty of Public Health, Universitas Airlangga.

Sang, A., Djajakusli, R. and Russeng, S. S. (2013) Hubungan Risiko Postur Kerja dengan Keluhan Musculoskeletal Disorders (MSDs) pada Pemanen Kelapa Sawit Di PT. Sinergi Perkebunan Nusantara. Scientific Articles. Makassar: Faculty of Public Health, Universitas Hasanuddin.

Sastrowinoto, S. (1985) Meningkatkan Produktivitas dengan Ergonomi. Jakarta: Pustaka Binaman Pressindo.

Sholihah, Q. (2013) Keselamatan dan Kesehatan Kerja: Konsep, Perkembangan dan Implementasi Budaya Keselamatan. Jakarta: Penerbit Buku Kedokteran EGC.

Tarwaka (2011) Ergonomi Industri. Surakarta: Harapan Press Solo.

Tarwaka (2014) Ergonomi Industri: Dasar-Dasar Ergonomi dan Implementasi di Tempat Kerja. 2nd edn. Surakarta: Harapan Press. 